\title{
Penggunaan Technology Acceptance Model Dalam Mengukur Kualitas Layanan Platform $E$-Commerce
}

\author{
Technology Acceptance Model Application for Measuring \\ E-Commerce Platform Service Quality
}

\author{
Hesti Maheswari ${ }^{1 *}$, Ruth Kiris D Siregar ${ }^{2}$ \\ ${ }^{1}$ Sekolah Bisnis dan Ekonomi, Universitas Prasetiya Mulya, Tangerang \\ ${ }^{2}$ Fakultas Ekonomi dan Bisnis, Universitas Pertamina, Jakarta \\ *Penulis korespondensi: Hesti Maheswari, hesti.maheswari@prasetiyamulya.ac.id
}

\begin{abstract}
Abstrak
Seiring dengan meningkatnya pertumbuhan e-commerce di Indonesia, ternyata jumlah pengaduan akan ketidakpuasan konsumen terhadap layanan e-commerce pun meningkat setiap tahunnya. Penelitian ini bertujuan menganalisis kualitas layanan e-commerce dalam meningkatkan kepuasan konsumen dengan technology acceptance model. Platform yang dianalisis dalam penelitian ini adalah Tokopedia dengan menggunakan bagan quality function deployment. Hasil analisis menunjukkan bahwa tingkat kepuasan konsumen masih berada di bawah tingkat harapan konsumen. Sistem yang user friendly, user interface yang simpel dan jelas, otomatisasi fitur saran, sistem pembayaran yang terintegrasi, dan membuat kolom pencarian terlihat jelas merupakan lima prioritas karakteristik teknis yang harus menjadi perhatian perusahaan karena sesuai dengan kebutuhan konsumen. Penelitian ini menyarankan kepada Tokopedia untuk melakukan evaluasi dan perbaikan secara berkala serta melakukan testing aplikasi secara rutin sehingga dapat meminimalisir terjadinya error dan bug. Tokopedia juga perlu lebih tanggap dengan keluhan pelanggan dan pihak pengembang bisa lebih update dalam menangani keluhan yang berkaitan dengan error dan ketidakstabilan aplikasi.
\end{abstract}

Kata kunci: E-commerce, Kualitas Pelayanan, Quality Function Deployment, Technology Acceptance Model.

\begin{abstract}
Along with the increasing growth of e-commerce in Indonesia, it turns out that the number of complaints about consumer dissatisfaction with e-commerce services also increases every year. This study aims to analyze the quality of e-commerce services in increasing consumer satisfaction with the technology acceptance model. The platform analyzed in this study is Tokopedia using a quality function deployment chart. The results of the analysis show that the level of consumer satisfaction is still below the level of consumer expectations. A user-friendly system, a simple and clear user interface, automated suggestion features, an integrated payment system, and making the search field clearly visible are the five priority technical characteristics that the company must pay attention to because it is in accordance with consumer needs. This research suggests to Tokopedia to evaluate and repair regularly and do regular application testing so as to minimize the occurrence of errors and bugs. Tokopedia also needs to be more responsive to customer complaints and developers can be more updated in handling complaints related to errors and application instability.
\end{abstract}

Keywords: E-commerce, Quality Function Deployment, Quality Service, Technology Acceptance Model

Informasi Artikel:

Diterima tanggal 3 Maret 2021; Disetujui tanggal 4 Desember 2021; Terbit online tanggal 30 Desember 2021 


\section{Pendahuluan}

Seiring dengan perkembangan teknologi yang kian pesat, jumlah pengguna internet di Indonesia pun terus meningkat. Berdasarkan data dari survei Asosiasi Penyelenggara Jasa Internet Indonesia (APJII), pada tahun 2020 pengguna internet di Indonesia telah mencapai 196,7 juta jiwa dengan penetrasi sebesar 73,7 persen dari total populasi (Riyanto, 2021). Pengakses internet di tahun 2018 tumbuh 9,4\% dari tahun 2017 dan tumbuh lebih dari 600\% dalam 10 tahun terakhir (APJII, 2018). Berdasarkan APJII, kondisi ini dipengaruhi oleh teknologi yang terus berkembang, meluasnya jangkauan internet dan pilihan gadget yang semakin bervariasi dan murah. Peningkatan ini tentu menjadi peluang bagi bisnis $e$-commerce untuk meningkatkan eksistensinya dalam menjangkau calon konsumen.

Sekalipun tingkat penetrasi ecommerce di Indonesia terus mengalami kenaikan dan diprediksi akan terus mengalami peningkatan baik dari sisi pangsa pasar maupun tingkat penetrasinya, namun ternyata tingkat penggunaan yang tinggi ini berbanding terbalik dengan nilai pasar ecommerce di Indonesia. Nilai pasar ecommerce Indonesia masuk dalam kategori rendah dibandingkan dengan rata-rata dunia. Besarnya pangsa pasar di Indonesia, menjadikan banyak e-commerce yang bermunculan dalam satu dekade ini. Setiap e-commerce saling bersaing dengan cara memberikan diskon untuk mendapatkan intensi calon konsumen.

Top e-commerce berdasarkan Ranking PlayStore di Kuartal I - 2017 hingga kuartal II - 2019 adalah Shopee. Tokopedia pada tahun sebelumnya di 2016 menempati posisi pertama, namun empat tahun ke belakang posisinya digantikan oleh Shopee. Kemudian di bawah Tokopedia, ada Lazada dan Bukalapak yang secara bergantian menempati urutan ketiga dan keempat. Kelebihan keempat e-commerce teratas ini memberikan kemudahan dalam berbagai fasilitas seperti kemudahan dan kenyamanan dalam bertransaksi sehingga konsumen merasa aman dan nyaman (Aryadita Hidayat dkk, 2017).

Seiring dengan pertumbuhan e-commerce khususnya platform belanja online, ternyata kasus pengaduan atas layanan e-commerce terhadap Yayasan Lembaga Konsumen Indonesia (YLKI) pun turut meningkat. Dari tahun 2015, pengaduan terhadap e-commerce masuk ke dalam 10 besar yaitu di posisi keempat. Peningkatkan akan hal ini pun terus naik setiap tahunnya. Terhitung pada tahun 2015 dari 77 kasus pengaduan terkait e-commerce, $20 \%$ di antaranya tentang refund bermasalah, $16 \%$ informasi produk yang tidak sesuai dengan barang, dan $15 \%$ pengiriman yang lama (APJI, 2017). Sementara itu, pada 2017 YLKI menerima pengaduan terkait layanan e-commerce, meningkat 2 kali lipat dari tahun 2016. Menurut YLKI, konsumen kerap mengeluhkan respon komplain yang lambat, belum diterimanya barang, sistem yang merugikan, tidak diberikannya refund, dugaan penipuan, barang yang dibeli tidak sesuai, dugaan kejahatan siber, keluhan mengenai cacat produk, pelayanan, harga, informasi, dan terlambatnya pengiriman barang. Data selengkapnya terkait aduan akan $e$ commerce dapat diperhatikan melalui Gambar 1. Gambar 1 menunjukkan bahwa bahwa respon complain sangat lambat, banyak keluhan belum diterimanya barang, dan sistem yang merugikan konsumen merupakan tiga item dengan persentase aduan tertinggi pada tahun 2017. 


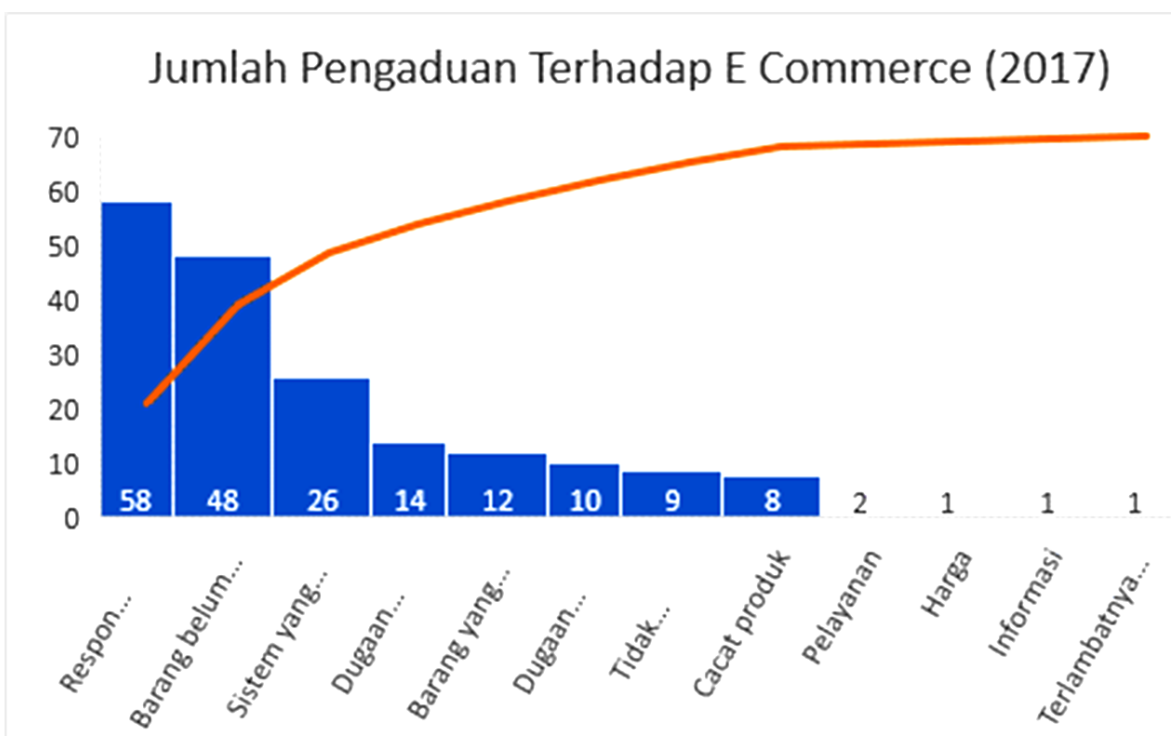

Gambar 1. Jumlah pengaduan terhadap e-commerce (2017)

Bisnis e-commerce telah terbukti menggerakkan perekonomian Indonesia bahkan kinerjanya semakin baik pada masa pandemi. Pertumbuhan volume transaksi e-commerce pada September 2020 mencapai sebanyak 150,16 juta transaksi, meningkat 79,38 persen secara tahunan, dari 83,71 juta transaksi pada September 2019. Tidak hanya dari jumlah transaksi, jual beli pada platform e-commerce mencapai Rp180,74 triliun per September 2020 (Elena, 2020). Jika kinerja bisnis e-commerce ini tidak dijaga dan pengaduan atau keluhan tidak terlayani dengan baik, suatu saat model bisnis seperti ini akan ditinggalkan konsumen. Oleh karena itu kajian kualitas layanan e-commerce tentunya menjadi hal yang menarik untuk dikaji lebih dalam. Karena kualitas website termasuk platform atau aplikasi e-commerce sangat berpengaruh terhadap banyaknya pelanggan yang akan mengakses dan memutuskan untuk berbelanja menggunakan e-commerce (Aryadita $\mathrm{H}$, dkk, 2017). Beberapa hal yang menjadi fokus penelitian ini di antaranya:

1. Menganalisis sejauh mana kepuasan konsumen terhadap layanan yang diberikan bisnis $e$ commerce yang didasarkan pada dimensi Technology Acceptance Model. Kualitas ecommerce ditentukan oleh nilai tambah yang diberikan pada produk atau jasa dan bagaimana pengguna menanggapinya.

2. Mengetahui kesenjangan yang terjadi antara persepsi pelanggan dengan keinginan pelanggan

3. Memetakan karakteristik platform e-commerce yang diterapkan pada saat ini

4. Mengembangkan design baru bisnis e-commerce yang sesuai dengan harapan pelanggan

\section{Tinjauan Pustaka}

\subsection{Technology Acceptance Model}

Technology Acceptance Model (TAM) diadaptasi dari theory of reasoned action (TRA) yang menjelaskan bahwa perilaku pengguna teknologi terhadap system atau teknologi informasi ditentukan oleh dua keyakinan, yaitu manfaat yang dirasakan (perceived usefulness) dan kemudahan yang diperoleh (perceived ease of use). Perceived Usefulness diartikan sebagai sejauh mana seseorang akan percaya bahwa dengan menggunakan sistem tertentu akan meningkatkan kinerja pekerjaannya. Hal ini dapat menjelaskan manfaat teknologi dari sisi penggunaannya yang berhubungan dengan berbagai macam aspek. Terdapat beberapa indikator dari persepsi kemanfaatan penggunaan sistem informasi atau perceived ease of use (Pratitis dan Maheswari, 2021) yaitu: meningkatkan produktivitas, memperbaiki atau mempermudah pekerjaan, efisien, efektif, meningkatkan kinerja. TAM juga banyak digunakan untuk mengukur niat konsumen untuk melakukan pembelian ulang (Rachbini, dkk., 2019; 
Pertawijaya, 2015; dan Rio, dkk., 2016). TAM dipandang dapat mengembangkan masa depan bisnis (Chutur, 2009).

Selanjutnya, faktor yang mempengaruhi penerimaan teknologi menurut Davis (Valencia, dkk., 2019) dapat dilihat pada Gambar 2 berikut:

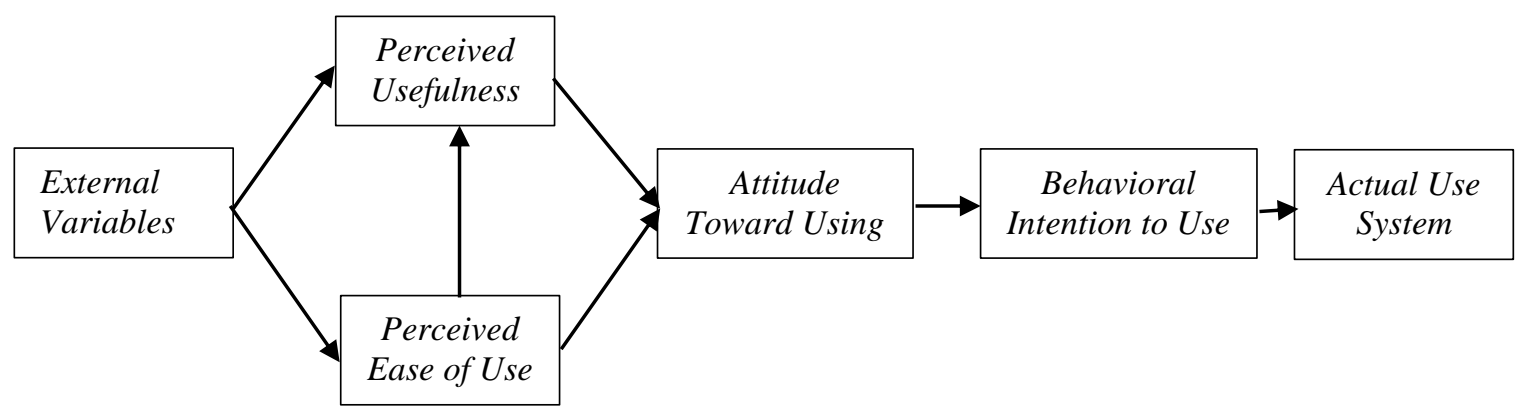

Gambar 2. Technology Acceptance Model

\subsection{Kualitas Jasa e-Commerce}

Menurut (Parasuraman \& Berry, 1985) kualitas pelayanan merupakan upaya pemenuhan kebutuhan serta keinginan konsumen suatu penyampaian dengan tujuan untuk mengimbangi harapan karyawan. Kualitas layanan digunakan sebagai tolak ukur sejauh mana tingkat pelayanan yang diberikan mampu sesuai dengan harapan konsumen. Salah satu faktor yang bisa menentukan tingkat keberhasilan dan kualitas perusahaan yakni bagaimana kemampuan perusahaan dalam memberikan pelayanan kepada pelanggan (Parasuraman \& Berry, 1985).

Sementara menurut konsep Taguchi, kualitas didefinisikan sebagai suatu kerugian yang ditimbulkan oleh sebuah produk bagi masyarakat setelah produk tersebut dikirim termasuk di dalamnya kerugian yang disebabkan oleh fungsi intrinsik produk itu sendiri. Strateginya dikhususkan pada loss function yang mengartikan bahwa setiap penyimpangan dari target menjadi kerugian yang dibayar konsumen (Heizer dan Rander, 2017). W. E. Deming berpendapat bahwa kualitas terjadi karena samanya kebutuhan dan kepuasan konsumen dengan harapan konsumen tersebut akan sebuah produk atau pun jasa dan secara berkelanjutan dengan harga yang telah disepakati (Evans and Lindsay, 2014).

Deming memastikan kualitas pada perbaikan dan pengukuran kualitas secara berkala serta fokus pada proses untuk mengeliminasi variasi karena sebagian besar dapat dikendalikan manajemen. Pemberian suatu kinerja atau tindakan untuk memenuhi kebutuhan secara tak kasat mata diartikan sebagai jasa. Pada dasarnya jasa diproduksi dan dikonsumsi secara bersamaan, di mana interaksi antara pemberi jasa dan penerima jasa mempengaruhi hasil dari jasa tersebut. Dengan mengelaborasi beberapa konsep tentang TAM dan kualitas, penelitian ini menggunakan perceived usefulness, pearceived ease of use, actual use system, attitude toward using platform, dan behavioral intention to use sebagai variabel yang analisis dengan indikator-indikator pada Tabel 1. 
Tabel 1. Variabel penelitian dan indikator

\begin{tabular}{|l|l|}
\hline \multicolumn{1}{|c|}{ Variabel } & \multicolumn{1}{c|}{ Indikator } \\
\hline & 1. Fleksibilitas penggunaan \\
2. Kemudahan untuk dipelajari dan dipahami \\
Perceived ease of use (XA) & 3. Nyaman digunakan \\
& 4. Kemudahan penggunaan/pengoperasian (user friendly) \\
& 5. Proses login dan mendaftar mudah \\
6. Stabil dan tidak ada kerusakan/error
\end{tabular}

3. Hasil dan Pembahasan

\subsection{Profil Responden}

Karakteristik responden pada penelitian ini dijelaskan pada Tabel 2 berikut:

Tabel 2. Karakteristik responden

\begin{tabular}{|l|l|c|l|l|c|}
\hline $\begin{array}{c}\text { Karakteristik } \\
\text { Responden }\end{array}$ & Keterangan & Jumlah & $\begin{array}{c}\text { Karakteristik } \\
\text { Responden }\end{array}$ & Keterangan & Jumlah \\
\hline Jenis kelamin & Pria & 80 & Pekerjaan & Karyawan & 36 \\
& Wanita & 167 & & Pelajar & 176 \\
& & & & PNS & 13 \\
& $<17$ & 48 & Tempat tinggal & Wiraswasta & 22 \\
\hline Usia & $17-25$ & 154 & & Bekasi & 38 \\
& $26-35$ & 44 & & Bogor & 21 \\
& $>36$ & 1 & & Depok & 11 \\
& & & & Tangerang & 33 \\
& & & & & 137 \\
\hline
\end{tabular}

\subsection{Hasil Uji Validitas dan Reliabilitas}

Uji validitas dilakukan dengan cara mengkorelasikan antara skor yang diperoleh masingmasing indikator dengan skor total. Dengan tingkat kesalahan 6\% dan jumlah sampel 247, maka diperoleh nilai $r$ kritis $=0.119$. Berdasarkan hasil uji validitas yang dilakukan terhadap seluruh indikator pada 5 dimensi Technology Acceptance Model dapat disimpulkan bahwa seluruh item pernyataan valid dan layak digunakan pada tahap selanjutnya. Data lengkap hasil uji validitas disajikan pada Tabel 3 berikut: 
Tabel 3. Hasil uji validitas

\begin{tabular}{|c|c|c|c|}
\hline Variabel & Item Pertanyaan & r hitung & Keterangan \\
\hline \multirow{6}{*}{$\begin{array}{l}\text { Perceived } \\
\text { Ease of Used } \\
(X A)\end{array}$} & Fleksibilitas Penggunaan & 0,637 & Valid \\
\hline & Kemudahan untuk dipelajari dan dipahami & & Valid \\
\hline & Nyaman digunakan & 0,852 & Valid \\
\hline & Kemudahan penggunaan dan pengoperasian & 0,876 & Valid \\
\hline & Respon yang cepat & 0,844 & Valid \\
\hline & Stabil dan tidak ada kerusakan/error & 0,785 & Valid \\
\hline \multirow{7}{*}{$\begin{array}{l}\text { Perceived } \\
\text { Usefulness } \\
(X B)\end{array}$} & Dapat meningkatkan efektivitas & 0,744 & Valid \\
\hline & Pilihan pembayaran platform beragam & 0,810 & Valid \\
\hline & Pilihan ekspedisi pengiriman platform beragam & 0,855 & Valid \\
\hline & Produk yang direkomendasikan relevan & 0,884 & Valid \\
\hline & Informasi yang disediakan up to date & 0,887 & Valid \\
\hline & Informasi yang diberikan akurat & 0,844 & Valid \\
\hline & Proses loading tidak memakan waktu & 0,784 & Valid \\
\hline \multirow{4}{*}{$\begin{array}{l}\text { Actual Use } \\
\text { System }(X C)\end{array}$} & $\begin{array}{l}\text { Percaya bahwa aplikasi dapat dijalankan dengan } \\
\text { baik }\end{array}$ & 0,872 & Valid \\
\hline & Rasa puas menggunakan aplikasi & 0,903 & Valid \\
\hline & Rasa bangga menggunakan aplikasi & 0,903 & Valid \\
\hline & $\begin{array}{l}\text { Pengalaman menyenangkan menggunakan } \\
\text { aplikasi }\end{array}$ & 0,889 & Valid \\
\hline \multirow{4}{*}{ Trust $(X D)$} & Percaya bahwa aplikasi meningkatkan kinerja & 0,844 & Valid \\
\hline & Percaya akan keamanan bertransaksi & 0,870 & Valid \\
\hline & Percaya akan validitas aplikasi & 0,879 & Valid \\
\hline & $\begin{array}{l}\text { Percaya bahwa aplikasi memberikan } \\
\text { kenyamanan }\end{array}$ & 0,854 & Valid \\
\hline \multirow{3}{*}{$\begin{array}{l}\text { Behavior to } \\
\text { Use (X5) }\end{array}$} & Niat menggunakan aplikasi & 0,903 & Valid \\
\hline & Niat menggunakan aplikasi di kemudian hari & 0,912 & Valid \\
\hline & Niat menggunakan aplikasi (n) bulan ke depan & 0,923 & Valid \\
\hline
\end{tabular}

Selain uji validitas, uji reliabilitas juga perlu dilakukan. Tujuan melakukan uji reliabilitas adalah untuk melihat apakah kuesioner memiliki konsistensi hasil jika dilakukan pengukuran dengan kuesioner tersebut secara berulang-ulang. Suatu variable dapat dikatakan reliabel dan handal ketika jawaban responden terhadap pernyataan selalu konsisten. Suatu variabel akan reliabel jika nilai Cronbach Alpha $>0.60$. Hasil uji reliabilitas untuk semua variabel adalah di atas 0,60 (Tabel 4). Hal ini menunjukkan bahwa seluruh variabel memenuhi syarat reliabilitas.

Tabel 4. Hasil uji reliabilitas

\begin{tabular}{|l|c|c|}
\hline \multicolumn{1}{|c|}{ Variabel } & Nilai Cronbach Alpha & Keterangan \\
\hline Perceived Ease of Used & 0,886 & Reliabel \\
\hline Perceived Usefulness & 0,920 & Reliabel \\
\hline Actual Ease of Use & 0,909 & Reliabel \\
\hline Attitude towards using technology & 0,874 & Reliabel \\
\hline Behavioral intention to use & 0,887 & Reliabel \\
\hline
\end{tabular}

\subsection{Importance Performance Analysis}

Untuk mengetahui indikator yang kinerjanya belum maksimal dalam meningkatkan kepuasan konsumen, penelitian ini menerapkan Importance Performance analysis (IPA). IPA sebaiknya dilakukan sebelum melakukan analisis kualitas dengan quality function deployment (QFD) (Maheswari, H dan Haningsih L, 2014). Indikator yang berada pada ruang 2 matriks IPA adalah indikator yang mempunyai kinerja baik sehingga tidak perlu masuk ke tahap analisis 
kualitas dengan QFD (Priadi R, dan Maheswari H, 2010). Analisis IPA dilakukan dengan bantuan SPSS dengan membandingkan antara kinerja dengan harapan konsumen. Diagram kartesius untuk hasil analisis IPA dapat diperhatikan pada gambar 3 berikut ini:

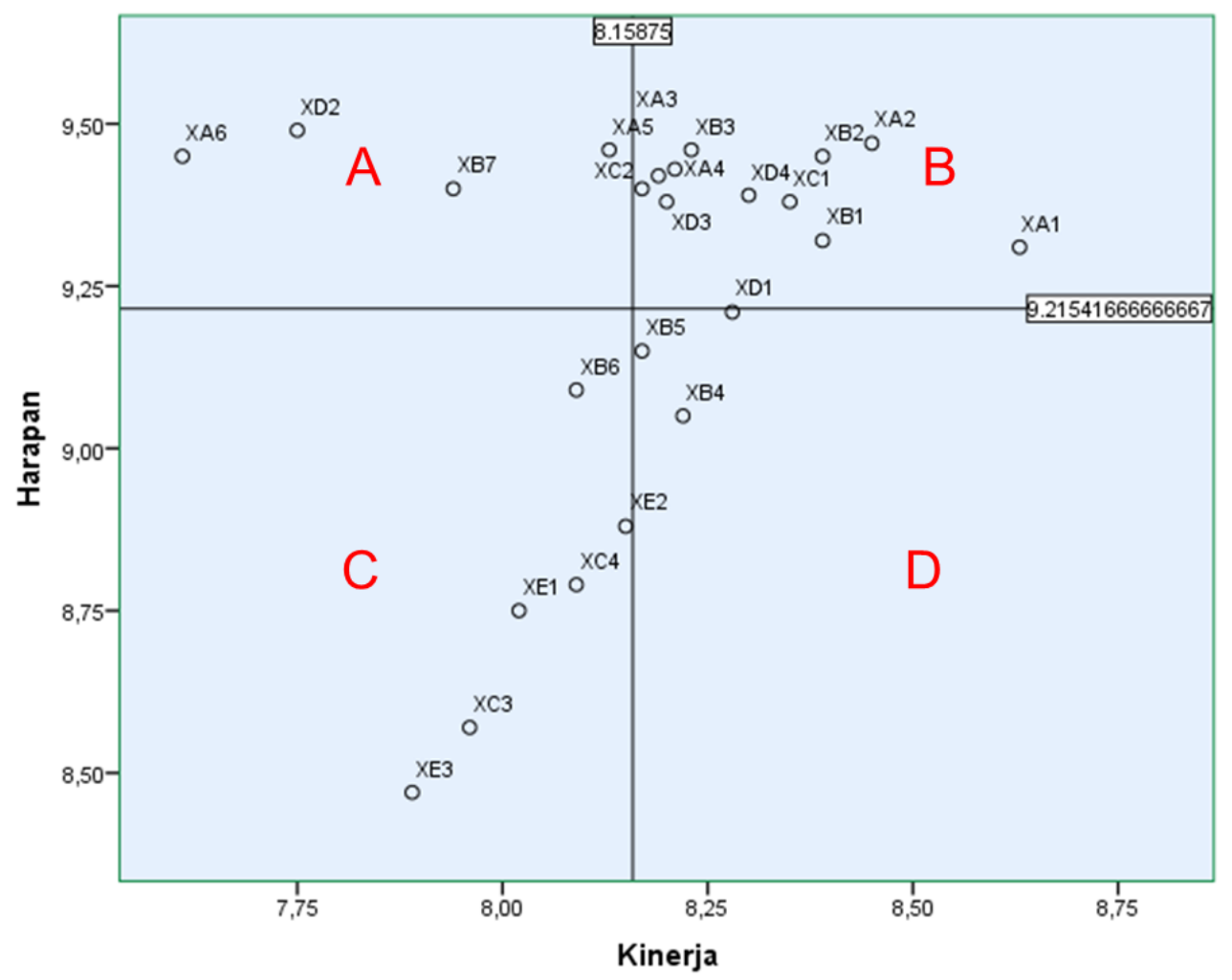

Gambar 3. Importance Performance Analysis

Kuadran A matriks IPA menjadi prioritas utama perbaikan karena indikator-indikator pada kuadran ini sangat penting bagi konsumen, namun belum memuaskan mereka. Terdapat 4 item pada bagian A, yaitu aplikasi stabil dan tidak sering terjadi gangguan (error); percaya pada keamanan bertransaksi; Fitur simpel dan memungkinkan berinteraksi dengan seller; serta proses login dan mendaftar mudah. Keempat indikator ini mempunyai kinerja di bawah rata-rata dan harus dianalisis lebih lanjut.

Kuadran B merupakan area ideal yang perlu dipertahankan karena indikator yang berada pada area ini memiliki kinerja yang baik. Konsumen merasa indikator ini penting dan bersamaan dengan itu konsumen merasa puas. Terdapat 11 indikator yang masuk dalam kuadran B, yaitu fleksibilitas penggunaan; kemudahan untuk dipelajari dan dipahami; nyaman digunakan; kemudahan penggunaan dan pengoperasian; dapat melihat review produk; pilihan pembayaran platform beragam; percaya bahwa aplikasi dapat dijalankan dengan baik; rasa puas menggunakan aplikasi; percaya akan validitas aplikasi serta percaya bahwa aplikasi memberikan kenyamanan.

Kuadran $\mathrm{C}$ merupakan area dengan prioritas yang rendah karena indikator yang masuk ruang ini merupakan indikator yang dianggap konsumen kurang penting, sehingga konsumen kurang atau tidak puas tidak menyebabkan masalah yang berarti. Terdapat enam indikator yang masuk kuadran $\mathrm{C}$, yaitu keakuratan informasi yang diberikan; rasa bangga menggunakan aplikasi; rasa puas menggunakan aplikasi; pengalaman menyenangkan menggunakan aplikasi; fitur yang ada mempermudah untuk membeli produk; timbul keinginan untuk terus membuka platform serta niat menggunakan aplikasi. 
Kuadran D merupakan ruang yang dianggap kurang penting oleh konsumen namun kinerja pelayanan perusahaan sangat baik bahkan berlebihan. Terdapat tiga item yang pelayanannya dianggap berlebihan, yaitu produk yang direkomendasikan relevan; informasi yang disediakan up to date dan percaya bahwa aplikasi dapat meningkatkan kinerja.

\subsection{Customer Requirement (1st Room)}

Setelah dilakukan importance performa analysis, dari 24 indikator, hanya 6 indikator yang tidak perlu dimasukkan ke dalam bagan house of quality karena berada di kuadran dengan prioritas yang rendah. Ke enam indikator tersebut yaitu informasi yang diberikan akurat; rasa bangga menggunakan aplikasi; pengalaman menyenangkan menggunakan aplikasi; fitur yang ada mempermudah untuk membeli produk; timbul keinginan untuk terus membuka platform; niat menggunakan aplikasi n bulan ke depan. Sehingga hanya 18 indikator yang masuk ruang customer requirement (ruang $1 \mathrm{HOQ}$ ) seperti pada Tabel 5 berikut ini:

Tabel 5. Customer requirements

\begin{tabular}{|c|c|}
\hline Variabel & Customer Requirements \\
\hline Perceived ease of use & $\begin{array}{l}\text { 1. Flesibilitas penggunaan } \\
\text { 2. Kemudahan dipelajari dan dipahami } \\
\text { 3. Kenyamanan pada saat digunakan } \\
\text { 4. Kemudahan penggunaan dan pengoperasian } \\
\text { 5. Stabil dan tidak ada kerusakan }\end{array}$ \\
\hline Perceived usefulness & $\begin{array}{l}\text { 1. Dapat melihat review produk } \\
\text { 2. Pilihan pembayaran platform beragam } \\
\text { 3. Pilihan ekspedisi pengiriman beragam } \\
\text { 4. Produk yang direkomendasikan beragam } \\
\text { 5. Informasi yang disediakan up to date } \\
\text { 6. Fitur simple dan memungkinkan berinteraksi dengan seller }\end{array}$ \\
\hline Actual use system & $\begin{array}{l}\text { 1. Keyakinan aplikasi berfungsi baik } \\
\text { 2. Puas dalam menggunakan aplikasi }\end{array}$ \\
\hline $\begin{array}{l}\text { Attitude toward using } \\
\text { technology }\end{array}$ & $\begin{array}{l}\text { 1. Kinerja aplikasi baik } \\
\text { 2. Keamanan bertransaksi } \\
\text { 3. Validitas aplikasi } \\
\text { 4. Kenyamanan bertransaksi }\end{array}$ \\
\hline
\end{tabular}

\subsection{Planning Matrix (2nd Room)}

Ruang dua pada bagan QFD membandingkan antara kinerja platform Tokopedia dengan harapan konsumen terhadap platform tersebut. Rata-rata konsumen menganggap seluruh indikator dalam ruang customer requirements sangat penting. Ketika kepentingan pelanggan tinggi, maka pihak perusahaan harus menjadikannya prioritas utama untuk segera diperbaiki (Menurut Patiunus, 2009). Langkah awal untuk memperbaiki kinerja bisnis adalah dengan membandingkan kekuatan bisnis dengan kekuatan pesaing (Maheswari, Rizki, Chandra, 2013). 
Tabel 6. Tingkat kesenjangan

\begin{tabular}{|c|l|c|c|c|}
\hline No & \multicolumn{1}{|c|}{ Indikator } & Kinerja & Harapan & GAP \\
\hline 1 & Fleksibilitas Penggunaan & 8,63 & 9,31 & $-0,68$ \\
\hline 2 & Kemudahan untuk dipelajari dan dipahami & 8,45 & 9,47 & $-1,02$ \\
\hline 3 & Nyaman digunakan & 8,19 & 9,42 & $-1,23$ \\
\hline 4 & Kemudahan penggunaan dan pengoperasian & 8,21 & 9,43 & $-1,21$ \\
\hline 5 & Proses login dan mendaftar mudah & 8,13 & 9,46 & $-1,33$ \\
\hline 6 & Stabil dan tidak ada kerusakan/error & 7,61 & 9,45 & $-1,85$ \\
\hline 7 & Dapat melihat review produk & 8,39 & 9,32 & $-0,92$ \\
\hline 8 & Pilihan pembayaran platform beragam & 8,39 & 9,45 & $-1,06$ \\
\hline 9 & Pilihan ekspedisi pengiriman platform beragam & 8,23 & 9,46 & $-1,23$ \\
\hline 10 & Produk yang direkomendasikan relevan & 8,22 & 9,05 & $-0,83$ \\
\hline 11 & Informasi yang disediakan up to date & 8,17 & 9,15 & $-0,98$ \\
\hline 12 & Fitur simple dan memungkinkan berinteraksi dengan seller & 7,94 & 9,40 & $-1,46$ \\
\hline 13 & Percaya bahwa aplikasi dapat dijalankan dengan baik & 8,35 & 9,38 & $-1,04$ \\
\hline 14 & Rasa puas menggunakan aplikasi & 8,17 & 9,40 & $-1,24$ \\
\hline 15 & Percaya bahwa aplikasi meningkatkan kinerja & 8,28 & 9,21 & $-0,94$ \\
\hline 16 & Percaya akan keamanan bertransaksi & 7,75 & 9,49 & $-1,74$ \\
\hline 17 & Percaya akan validitas aplikasi & 8,20 & 9,38 & $-1,18$ \\
\hline 18 & Percaya bahwa aplikasi memberikan kenyamanan & 8,30 & 9,39 & $-1,09$ \\
\hline
\end{tabular}

Sebelum membandingkan kinerja bisnis dengan pesaing, tahap pertama pada Planning matrix adalah menganalisis gap antara tingkat kepentingan dengan tingkat kepuasan konsumen pada seluruh atribut atau kebutuhan konsumen akan layanan Tokopedia yang disajikan pada Tabel 6. 15 kategori di mana pelanggan merasa sangat puas dan 3 kategori lainnya, pelanggan merasa puas. Angka terendah berada pada kategori kepercayaan konsumen terkait keamanan bertransaksi dengan Tokopedia. Hal ini tentunya akan menjadi perhatian utama mengingat menjaga kepercayaan pelanggan adalah hal yang sangat penting dalam bisnis jasa (Jayashree, dkk., 2021).

Mayoritas customer requirements mempunyai gap negatif yang sekaligus menunjukkan bahwa kepuasan konsumen masih berada di bawah harapan konsumen. Indikator "stabil dan tidak ada kerusakan/error" dan "percaya akan keamanan bertransaksi”" merupakan 2 indikator dengan nilai kesenjangan tertinggi.

Pada Gambar 4, customer competitive assessment, menunjukkan perbandingan penilaian pelanggan terhadap ketiga platform. Pada penelitian ini, Tokopedia sebagai perusahaan yang diteliti dibandingkan dengan Shopee dan Bukalapak. Rata-rata tingkat kepuasan konsumen terhadap platform Tokopedia berada di antara Shopee dan Bukalapak. Tepatnya di bawah Shopee namun masih di atas Bukalapak. Dari analisis ini perusahaan dapat mengetahui bahwa kinerja pada 16 customer requirements masih harus ditingkatkan. 


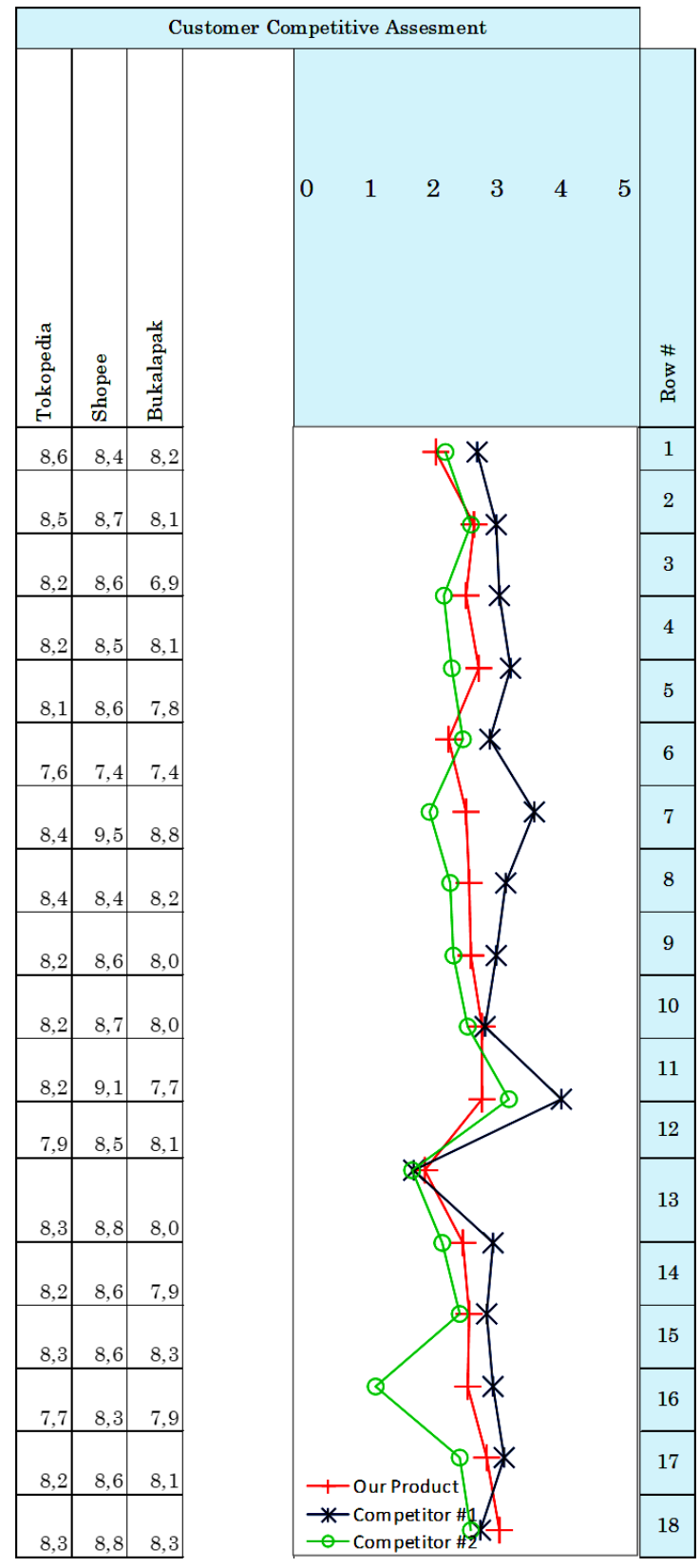

Gambar 4. Customer competitive assessment

Berdasarkan matriks customer competitive assessment seperti yang ditunjukkan pada Gambar 3 di atas, Tokopedia unggul 3 indikator dari 18 indikator yang dibandingkan dengan pesaing. 3 indikator tersebut adalah: produk yang direkomendasikan beragam, percaya bahwa aplikasi dapat dijalankan dengan baik, dan percaya bahwa platform memberikan kenyamanan. Sedangan 15 item lainnya diungguli oleh platform Shopee.

\subsection{Technical Characteristic (3rd Room)}

Karakteristik teknis menggambarkan atribut yang menunjukkan keunggulan Tokopedia sebagai platform yang diteliti. Dengan mewawancarai pimpinan Tokopedia dan hasil observasi melalui jurnal dan pengetahuan penulis, karakteristik teknikal dari Tokopedia untuk memenuhi kebutuhan konsumen adalah 1) data terenskripsi; 2) mengaktifkan fitur review dan wishlist; 3) otomatisasi fitur saran (auto suggestion); 4) sistem pembayaran yang terintegrasi; 5) system pengiriman terintegrasi; 6) membuat kolom pencarian terlihat jelas; 7) sistem yang user friendly; 8) otomatisasi komunikasi dan fitur chat, 
9) notifikasi jelas dan up to date serta 10) User interface yang simple dan jelas. Selama proses wawancara dibahas pula arah pengembangan dengan hasil 5 karakteristik teknis masih harus ditingkatkan kinerjanya sehingga memiliki arah pengembangan berupa anak panah ke atas seperti ditunjukkan pada Gambar 5 di bawah ini. Selain itu, arah anak panas keatas mengisyaratkan bahwa semakin tinggi target semakin baik. Untuk 5 karakteristik teknis lainnya telah optimal.

\subsection{Relationship (4th Room)}

Nilai analisis relationship dapat diperhatikan melalui Gambar 5 di bawah ini:

\begin{tabular}{|c|c|c|c|c|c|c|c|c|c|c|}
\hline Direction of Improvement & $\diamond$ & $\diamond$ & $\boldsymbol{\Delta}$ & $\boldsymbol{\Delta}$ & $\boldsymbol{\Delta}$ & $\diamond$ & $\Delta$ & $\diamond$ & $\diamond$ & $\boldsymbol{\Delta}$ \\
\hline $\begin{array}{c}\text { Customer } \\
\text { Requirements } \\
\text { (Explicit and } \\
\text { Implicit) }\end{array}$ & 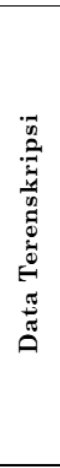 & 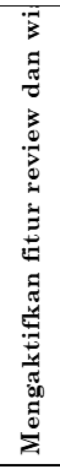 & 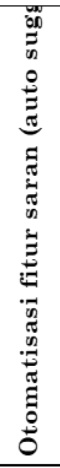 & 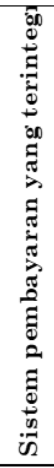 & 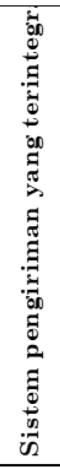 & 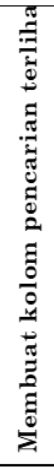 & 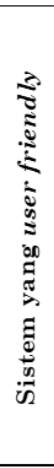 & 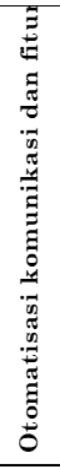 & 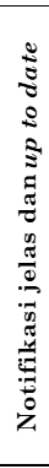 & 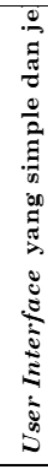 \\
\hline 1. Fleksibilitas penggunaan & & 0 & O & O & ○ & & O & O & $\mathrm{O}$ & 0 \\
\hline 2. Kemudahan untuk dipelajari dan dipahami & & & 0 & 0 & & & 0 & 0 & V & $\mathbf{0}$ \\
\hline 3. Nyaman digunakan & & & O & O & & & O & & O & \\
\hline 4. Kemudahan penggunaan dan pengoperasian & & & 0 & 0 & & & O & 0 & 0 & 0 \\
\hline 5. Proses login dan mendaftar mudah & & $\nabla$ & & & $\nabla$ & $\nabla$ & 0 & & $\mathrm{O}$ & \\
\hline 6. Stabil dan tidak ada kerusakan & & & $\mathrm{O}$ & & & & 0 & & & $\mathrm{O}$ \\
\hline 1. Dapat melihat review produk & & & $\mathrm{O}$ & & & & $\mathrm{O}$ & & O & \\
\hline 2. Plihan pembayaran platform beragam & & & & & & & $\mathrm{O}$ & $\mathrm{O}$ & O & $\mathrm{O}$ \\
\hline 3. Plihan eks pedis i pengiriman platform beragam & & & & V & & & $\nabla$ & $\mathrm{O}$ & & \\
\hline 4. Produk yang direkomendasikan beragam & & $\mathrm{O}$ & ○ & & & & $\mathrm{O}$ & & $\mathrm{O}$ & \\
\hline 5. Informasi yang disediakan platform up to date & & & $\mathrm{O}$ & & $\nabla$ & & & & O & \\
\hline $\begin{array}{l}\text { 6. Fitur simple dan memungkinkan berinteraksi } \\
\text { dengan seller }\end{array}$ & & & & $\mathrm{O}$ & $\mathrm{O}$ & & O & O & $\mathbf{O}$ & \\
\hline $\begin{array}{l}\text { 1. Percaya bahw a aplikasi dapat dijalankan } \\
\text { dengan baik }\end{array}$ & $\mathrm{O}$ & $\mathrm{O}$ & $\mathrm{O}$ & O & & & $\mathrm{O}$ & $\mathrm{O}$ & & \\
\hline 2. Rasa puas menggunakan aplikasi & & $\nabla$ & & $\mathrm{O}$ & & & $\mathrm{O}$ & & & \\
\hline 1. Percaya bahw a aplikas i meningkatkan kinerja & & & & & & & $\mathrm{O}$ & & $\mathrm{O}$ & \\
\hline 2. Percaya akan keamanan bertransaksi & & & & & $\mathrm{O}$ & & & & & \\
\hline 3. Percaya akan validitas aplikasi & $\mathrm{O}$ & $\nabla$ & & & & & & & & \\
\hline $\begin{array}{l}\text { 4. Percaya bahw a aplikas imemberikan } \\
\text { kenyamanan }\end{array}$ & & $\mathrm{O}$ & & $\mathrm{O}$ & & & & & & \\
\hline
\end{tabular}

Gambar 5. Relationship matrix 
Pemberian nilai hubungan yang dibuat pada ruang relationship matrix (forth room) bersifat subyektif berdasarkan data yang diperoleh peneliti melalui wawancara dengan pihak terkait, observasi lapangan serta pengetahuan penulis sebagai peneliti (Maheswari, Rizki, Chandra, 2013).

\subsection{Technical Correction $\left(5^{\text {th }}\right.$ Room)}

Ruangan kelima pada bagan HOQ memuat data berupa kolerasi teknis yang menunjukkan interaksi antar characteristic techniques. Bentuk korelasi teknis berupa atap, sehingga kerap dinamai roof matrix. Korelasi teknis untuk penelitian ini secara rinci dapat dilihat pada roof matrix (Gambar 6) sebagai berikut:

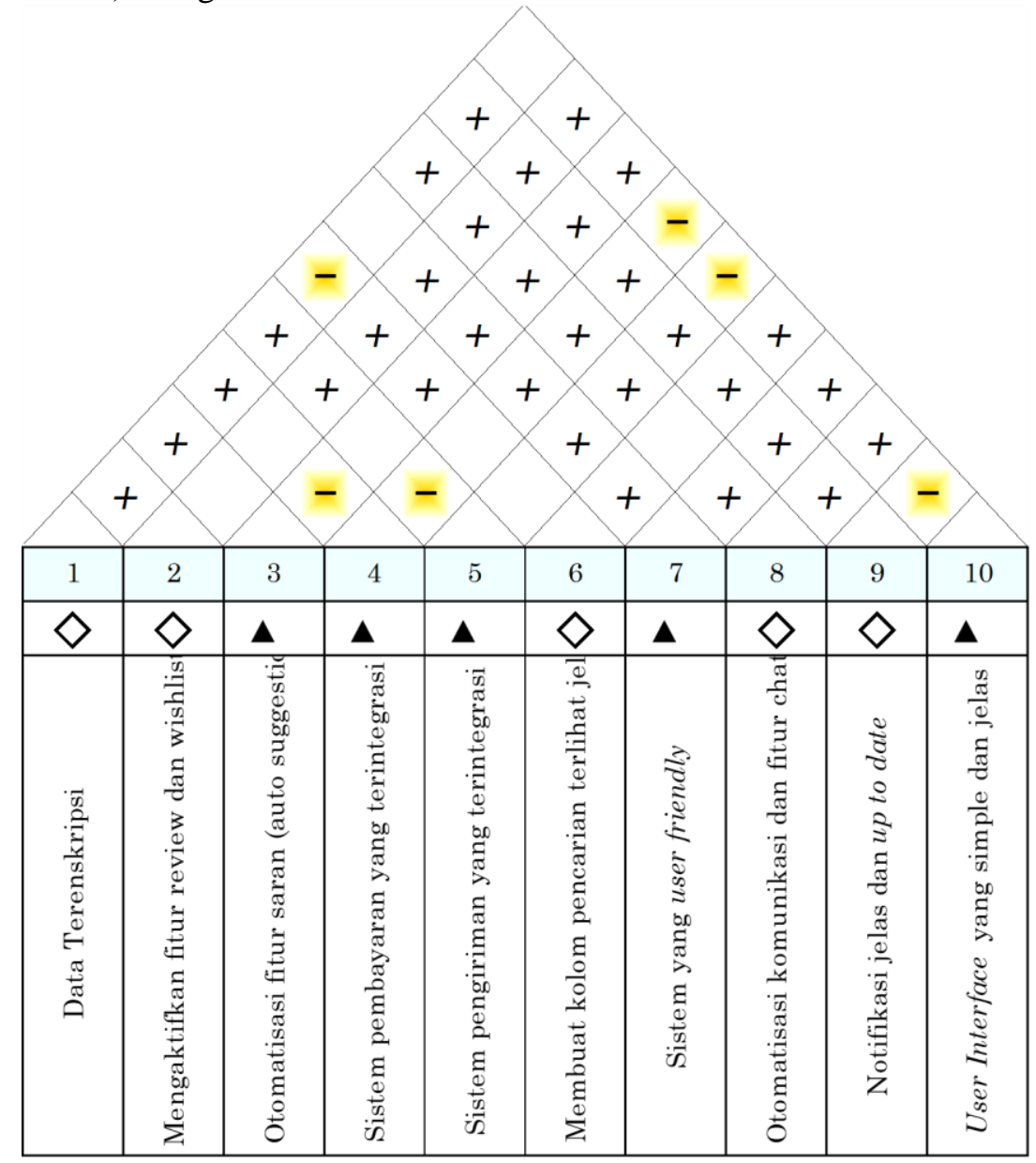

Gambar 6. Technical correlation analysis

Pada gambar 6, terlihat bahwa karakteristik teknis mendominasi hubungan dengan simbol + , yang artinya masing-masing karakteristik memiliki hubungan yang kuat satu sama lain. Hal ini berarti ketidakpuasan pada salah satu karakteristik yang disediakan akan mempengaruhi karakteristik yang lainnya (Maheswari, Rawikara, 2015). Ada 6 karakteristik yang berhubungan negatif dan 8 karakteristik untuk yang tidak memiliki hubungan sama sekali.

\subsection{Technical Matrix $\left(6^{\text {th }}\right.$ Room $)$}

Ruang ke enam dalam bagan house of quality merupakan technical matrix atau technical response. Ruangan ini terdiri dari technical importance rating dan relative weight (\%). Berikut pada Tabel 7 interpretasi dari analisis teknikal: 
Tabel 7. Technical matrix

\begin{tabular}{|r|c|c|c|c|c|c|c|c|c|c|}
\hline Max Relationship & 9 & 9 & 9 & 9 & 9 & 9 & 9 & 9 & 9 & 9 \\
\hline Technical Importance Rating & 84,029 & 371,6 & 464,91 & 506,99 & 495,5 & 554,51 & 605,88 & 505,51 & 471,86 & 632,75 \\
\hline Relative Weight & $2 \%$ & $8 \%$ & $10 \%$ & $11 \%$ & $11 \%$ & $12 \%$ & $13 \%$ & $11 \%$ & $10 \%$ & $13 \%$ \\
\hline & & & & & & & & & & \\
Weight Chart & & & & & & & & & \\
& & & & & & & & & \\
& & $\equiv$ & $\underline{\underline{\underline{\underline{\underline{\underline{\underline{E}}}}}}}$ \\
\hline
\end{tabular}

Technical response yang memiliki hubungan kuat dengan pelanggan, memiliki competitive performace yang baik. Pada data relative weight, relative weight diperoleh dari perhitungan nilai technical importance rating dibagi dengan jumlah total keseluruhan kemudian dikalikan 100\%. Karakteristik yang memiliki prioritas tertinggi dan perlu untuk digunakan dalam proses desain jasa maupun produk (Sri Winarti, 2009). Pada tabel 7, terlihat bahwa karateristik teknis yaitu user interface yang simpel dan jelas memiliki nilai technical importance rating tertinggi dengan jumlah 632,75. Oleh karena itu, bisa disimpulkan bahwa semakin besar nilai atau persentasenya maka akan semakin tinggi tingkat kepentingannya (Wijaya, 2018). Pada Tabel 8 berikut, akan dimuat secara rinci urutan prioritas perhatian karakteristik teknis perusahaan.

Tabel 8. Relative importance analysis

\begin{tabular}{|c|c|l|c|}
\hline $\begin{array}{c}\text { No. } \\
\text { Prioritas }\end{array}$ & $\begin{array}{c}\text { No. urut } \\
\text { karakteristik teknikal }\end{array}$ & \multicolumn{1}{|c|}{ Karakteristik teknikal } & $\begin{array}{c}\text { Relative } \\
\text { importance }\end{array}$ \\
\hline 1 & 10 & User interface yang simple dan jelas & $13 \%$ \\
\hline 2 & 7 & Sistem yang user friendly & $13 \%$ \\
\hline 3 & 6 & Membuat kolom pencarian terlihat jelas & $12 \%$ \\
\hline 4 & 4 & Sistem pembayaran yang terintegrasi & $11 \%$ \\
\hline 5 & 8 & Otomatisasi komunikasi dan fitur chat & $11 \%$ \\
\hline 6 & 5 & Sistem pengiriman yang terintegrasi & $11 \%$ \\
\hline 7 & 9 & Notifikasi jelas dan up to date & $10 \%$ \\
\hline 8 & 3 & Otomatisasi fitur saran (auto suggestion) & $10 \%$ \\
\hline 9 & 2 & Mengaktifkan fitur review dan wishlist & $8 \%$ \\
\hline 10 & 1 & Data terenskripsi & $2 \%$ \\
\hline
\end{tabular}

Dapat diperhatikan pada Tabel 8 , hasil analisis nilai relative importance menunjukkan bahwa user interface yang simpel dan jelas serta sistem yang user friendly merupakan karakteristik teknis yang menjadi prioritas pertama dalam evaluasi perbaikan kualitas layanan platform Tokopedia.

\section{Kesimpulan}

Melalui analisis data dan pembahasan yang telah dijelaskan pada bagian 3 artikel ini, maka peneliti dapat menarik beberapa kesimpulan, di antaranya:

1. Terdapat 24 kebutuhan konsumen terhadap platform Tokopedia yang dikelompokkan menurut dimensi Technology Acceptance Model .

2. Terdapat 18 atribut kebutuhan konsumen yang perlu dianalisis lebih lanjut dengan menggunakan bagan QFD untuk perbaikan ke depannya. Informasi yang diberikan akurat; rasa bangga menggunakan aplikasi; pengalaman menyenangkan menggunakan aplikasi; fitur yang ada mempermudah untuk membeli produk; timbul keinginan untuk terus membuka platform; dan niat menggunakan aplikasi $\mathrm{n}$ bulan ke depan berada pada kuadran $\mathrm{C}$ matriks IPA sehingga tidak perlu diinput ke dalam ruang 1 House Of Quality.

3. Nilai kepuasan konsumen terhadap aplikasi yang stabil dan tidak pernah mengalami error berada di bawah tingkat kepentingan dengan angka kesenjangan tertinggi. Secara keseluruhan analisis gap bernilai negatif yang menunjukkan bahwa kepuasannya kosnumen masih berada di bawah angka kepentingan. Oleh karena itu, perlu dilakukan riset secara 
4. User interface yang simpel dan jelas serta sistem yang user friendly merupakan prioritas utama perbaikan pada karakteristik teknis. Hal ini karena ke dua karakteristik tersebut memiliki nilai technical importance tertinggi dengan masing - masing bobot 632,75 dan 605,88. Untuk meningkatkan kualitas pelayanan yang sesuai dengan kebutuhan dan keinginan konsumen, perusahaan perlu melakukan uji kualitas dalam jangka waktu tertentu, sehingga pengembangan platform sesuai dengan harapan dan keinginan konsumen.

Melalui data dan simpulan di atas, maka terdapat beberapa saran dan masukan yang dapat diberikan peneliti, di antaranya:

1. Agar Tokopedia semakin dapat meningkatkan kualitasnya terutama dari sisi aplikasi yang akan dipakai pelanggan, akan lebih baik jika pengembangan dan perbaikan sistem difokuskan pada indikator dengan nilai gap tertinggi dalam hal ini "stabil dan tidak ada kerusakan" dan "percaya akan keamanan bertransaksi". Agar aplikasi semakin stabil dan tidak ada keusakan atau error perlu dilakukan evaluasi terus menerus. Pihak pengembang dalam hal ini tim IT perlu melakukan perbaikan secara berkala dan melakukan testing aplikasi secara rutin sehingga dapat meminimalisir terjadinya error dan bug. Selain itu, harus ada layanan untuk menerima keluhan pelanggan sehingga tim pengembang lebih update jika terjadi error dan ketidakstabilan aplikasi. Dalam indikator "percaya akan keamanan bertransaksi" perlu adanya enkripsi data untuk menjamin keamanan data pelanggan. Pihak pengembang perlu membuat aplikasi seaman mungkin, apalagi Tokopedia sebagai aplikasi layanan berbelanja yang sangat akrab dengan sistem pembayaran.

2. Untuk meningkatkan kualitas layanan dari sisi karakteristik teknikal sebaiknya perlu dilakukan penelitian dan evaluasi lebih lanjut terutama pada "user interface yang simple dan jelas" dan "sistem yang user friendly". Pembuatan tampilan aplikasi yang simple dan memungkinkan pengguna untuk mempelajari dan mengetahui menu - menu yang ada pada aplikasi secara mudah dan tanpa memakan waktu merupakan hal yang paling diinginkan konsumen.

3. Memperdalam penelitian Quality Function Deployment dengan menggunakan Technology Acceptance Model dan penambahan indikator secara mendetail sehingga evaluasi kualitas layanan bisa diperoleh sesuai dengan apa yang dibutuhkan konsumen

\section{Daftar Pustaka}

Akgil, Yakub (2018) 'An analysis of acceptance of internet banking: an integration of e-trust and service quality to the tam- the case of Turkey'

Aranningrum, W. (2013) 'Peningkatan kualitas pelayanan pegawai dengan menggunakan metode Importance Performance Analysis (IPA)-Quality Function Deployment (QFD)'

Arvie, Dhea \& Tanaamah, Andeka Rocky (2018) 'An analysis of the Technology Acceptance Model in understanding retailers behavioral intention to use paytm-a digital wallet'

Aryadita Himawat, dkk. (2017) 'Analisis kualitas layanan website e-commerce terhadap kepuasan pengguna menggunakan metode WEBQUAL 4.0.', Studia Informatika: Jurnal Sistem Informasi, hal 29-35.

Asosiasi Penyelenggara Jasa Internet Indonesia (2018). Berapa jumlah pengguna internet di indonesia? pengguna internet di indonesia (1998-2017) [Online] (Diakses Desember 2019)

Aufal Ahdy, Ahmad (2015) 'Analisis penerimaan mahasiswa pengguna e-commerce dengan menggunakan Technology Acceptance Model (Study kasus: OLX.CO.ID)', Surabaya: Institut Teknologi Sepuluh November

Bayu, Dimas Jarot (2017) YLKI: Keluhan terbanyak konsumen selama 2017 soal toko online. Tersedia di: https://katadata.co.id/yuliawati/berita/5e9a560abb7d3/ylki-keluhan-terbanyak-konsumen-selama2017-soal-toko-online. 
Cho, Kim \& Kwak (2015) 'Application of SERVQUAL and Fuzzy Quality Function Deployment to service improvement in service centres of electronic companies'

Daniel Cardona Valencia, dkk. (2019) 'Analysis of e-commerce acceptance using Technology Acceptance Model'

Dewi, A. R. (2009) 'Analisis faktor - faktor yang mempengaruhi penerimaan wajib pajak terhadap penggunaan e-filling', Semarang: Universitas Diponegoro.

Elena, Maria. (2020) Transaksi e-commerce meningkat 79,38 persen di tengah resesi ekonomi [Online]. Tersedia di: https://ekonomi.bisnis.com/read/20201109/9/1315333/transaksi-e-commerce-meningkat7938-persen-di-tengah-resesi-ekonomi (Diakses: 9 November 2020).

Gotzamani, Katerina D. \& Tzavlopoulo, Yannis E. (2009) 'Measuring e commerce quality: an exploratory review' Jurnal Internasional Kualitas dan Ilmu Layanan, Vol.1, No. 3, Emerald Group Publishing.

Harwani, Y. dan Maheswari H. (2015) 'Evaluation of operating public service performance in fulfillment community expectation in Jakarta', Mediterranean Journal of Social Sciences 6 (5 S5), 258

I. B. Suryaningrat, dkk. (2010) 'Aplikasi metode Quality Function Deployment untuk meningkatkan kualitas produk mie jagung'

Lee, Younghwa, Kozar, Kenneth A., dan Larsen, Rai R.T. (2003) 'The Technology Acceptance Model: past, present, and future', Communication of the Association for Information Systems: Vol.12, Article 50 .

Maheswari H. dan Haningsih L. (2010) 'Analisa perancangan ulang (redesain) model operasionalisasi program bantuan operasional sekolah dalam meningkatkan efektivitas penyelenggaraan pendidikan dan memenuhi harapan masyarakat', Jurnal Manajemen Imiah dan Bisnis, Vol 2 No 1 (2014). DOI: https://doi.org/10.31843/jmbi.v2i1.38

Maheswari, H., Rizki, M., dan Chandra, R. (2013) 'Evaluation of product quality bags bodypack fulfilling customer satisfaction', Sustainable Competitive Advantage (SCA), National Conference Universitas Jenderal Sudirman.

Maheswari, H. dan Rawikara, Y. (2015) 'Evaluasi perbaikan desain operasi pelayanan perbankan (Studi Kasus pada BPRS Berkah Mulia Abadi)', Jurnal Ilmiah Manajemen dan Bisnis Mercu Buana 1 (1), 97036, DOI: 10.22441/jimb.v1i1.566

Mohammad Chuttur (2009) 'Overview of the Technology Acceptance Model: origins, developments and future directions', Indiana University, USA, Sprouts: working papers on information systems, Vol. 9, No. 37 .

Paul J. Hu, Patrick Y.K. Chau, Olivia R. Liu Sheng, and Kar Yan Tam (1999) 'Examing the Technology Acceptance Model using physician acceptace of telemedicine', Journal of Management of Information Systems: Vol.16, No. 2.

Pertawijaya, Immar (2015) 'Analisis komparatif mobile Technology Acceptance Model pada aplikasi Telkom T Money dan Mandiri E Cash”, E-Proceeding of Management, Vol. 2, No. 2. 
Pratitis, Riska Wegig (2020) 'Evaluasi efektivitas penggunaaan aplikasi human resource information sistem i-am dalam meningkatkan kualitas layanan karyawan PT Pertamina (Persero)', Jakarta: Universitas Pertamina

Pratitis, R.W, dan Maheswari, H. (2021) 'The effectiveness of I-AM human resources information system application at PT. Pertamina (Persero)', Journal of Management and Energy Business, Vol 1(1), p. 13-23. https://doi.org/10.54595/jmeb.v1i1.17

Priadi H. dan Maheswari H. (2010) 'Analisis efektifitas Iklan Yamaha Jupiter Mx versi "Merobohkan Jembatan" terhadap dampak komunikasi diukur dengan metode Epic Model', Teropong, Vol. 2, hal 68-105.

Rachbini, Widarto, Salim, Fahruddin, Haque, Marisa Gace, dan Rahmawati, Emi (2019 'Analisis niat pembelian ulang e-commerce mobile dengan pendekatan Technology Acceptance Model', Jurnal Aplikasi Manajemen dan Bisnis, Vol. 5, No. 3.

Rahi, Samar, Mansour, Majeed Mustafa Othman, dan Alnaser, Feras mi dan Alghizzawi, Mahmoud (2019) 'Integration of UTAUT model in internet banking adoption context', Journal of research in Interactive

Rezeki, Rahmad dan Hernadewita (2018) 'Perancangan perbaikan kualitas layanan e-commerce dengan Quality Function Deployment: study pelanggan jakarta18'

Rio, Ahmad Syahputra (2016) 'Penggunaan technology acceptance model terhadap intensi pebisnis dalam menggunakan e-commerce', Lampung: Universitas Lampung

Riyanto, G.P. (2021) Jumlah pengguna internet indonesia 2020 tembus 202 juta [Online]. Tersedia di: https://tekno.kompas.com/read/2021/02/23/16100057 (Diakses: Januari 2021)

Rosarindry Poetri, Adellia (2010) 'Adopsi e-commerce dengan pendekatan technology acceptance model bagi ukm', Solo: UNS

Sudjana (2000) Metode statistika. Bandung.

Sugiyono (2017) Metode penelitian kuantitatif, kualitatif, dan R\&D. Alfabeta. Bandung.

Sunil, Chopra, \& Meindl, Peter (2016) Supply chain management strategy, planning and operation. United Stated: Pearson Education Limited.

Tero Pikkarainen, Kari Pikkarainen, dkk. (2004) 'Consumer acceptance of online banking: an extension of the technology acceptance model' Vol. 14, No. 3, Emerald group publishing

Utama, Ray dan Bagus, Gusti (2016) Teknik sampling dan penentuan Jumlah sampel [Online]. Tersedia di: https://www.researchgate.net/publication/289657773

Valencia, D.C., Valencia-Arias, A., Benjumea, M. L., Bran, L., Valencia, J. (2019) 'Analysis of ecommerce acceptance using the Technology Acceptance Model', SciPap 2019, 27(1), 984.

Wibisono, Dermawan (2013) Panduan menyusun skripsi, tesis dan disertasi. Penerbit Andi. Yogyakarta.

Wijaya, T. (2018) Manajemen kualitas jasa desain servqual, QFD dan kan., Indeks Jakarta. Jakarta. 
JOURNAL OF INTEGRATED SYSTEM VOL 4. NO. 2, DESEMBER 2021: 199-215

Winarti, Sri (2009) 'Analisis kualitas jasa pelayanan hypermarket yang efektif untuk meningkatkan kualitas pelayanan pelanggan melalui QFD’, Depok: Universitas Indonesia 